TARNOWSKIE STUDIA TEOLOGICZNE 35 (2016) NR 2, S. 163-167

http://dx.doi.org/10.15633/tst.2112

dk. Piotr Tajak

UNIWERSYTET PAPIESKI JANA PAWEA II W KRAKOWIE

\title{
Sesja naukowa Miłosierdzie Boga \\ (Tarnów, 19 lutego 2016 roku)
}

W dniu 19 lutego 2016 roku w Wyższym Seminarium Duchownym w Tarnowie odbyła się zorganizowana przez Wydział Teologiczny Sekcja w Tarnowie Uniwersytetu Papieskiego Jana Pawła II w Krakowie sesja naukowa pt. Miłosierdzie Boga. Głównym jej pomysłodawcą był biskup tarnowski Andrzej Jeż, a organizatorem dziekan Wydziału Teologicznego Sekcja w Tarnowie, ks. dr hab. Janusz Królikowski. Sesja ta, poświęcona tematyce miłosierdzia, rozpoczęła się wspólnym odmówieniem Koronki do Bożego Miłosierdzia w kaplicy seminarium duchownego. Po niej, już w auli seminaryjnej, odbyła się część naukowa.

Sesję otworzył rektor Wyższego Seminarium Duchownego w Tarnowie, ks. dr hab. Andrzej Michalik, który jako gospodarz przywitał organizatorów, prelegentów oraz wszystkich uczestników. Przypominając słowa papieża Franciszka, że "potrzebujemy nieustannie kontemplować tę tajemnicę miłosierdzia” (Franciszek, Misericordiae vultus, 2), zaznaczył, iż obecna sesja stworzyła nam szczególną możliwość kontemplowania tej tajemnicy. Następnie słowo do uczestników skierował biskup tarnowski Andrzej Jeż. W przemówieniu powiedział, że modląc się słowami „Dla Jego bolesnej męki, miej miłosierdzie dla nas i całego świata”, prosimy Boga Ojca, aby popatrzył na nas przez dzieło odkupienia Jego umiłowanego Syna. W ten sposób najwymowniej objawia się miłosierdzie Trójjedynego Boga. Chrystus jest bramą do tajemnicy wnętrza Boga, który jest Miłością miłosierną. W skazał na osobę papieża Franciszka, który wzorem dwóch świętych papieży - Jana XxıII i Jana Pawła II, dostrzegających znaki czasu i wzywających, by kwestię miłosierdzia postawić na nowo w centrum nauki i praktyki Kościoła - podobnie zachęca nas, żebyśmy tajemnicę miłosierdzia nieustannie kontemplowali. Zdaniem biskupa zauważamy dzisiaj, iż świat został zdekonstruowany przez wyrzucenie Boga poza życie całych społeczeństw, ale także, że wyrzucony 
Lekarz jest bardzo potrzebny chorującej społeczności świata, stąd olbrzymie otwarcie na tajemnicę Bożego miłosierdzia, która jest w stanie dogłębnie uzdrowić pojedynczego człowieka, a przez niego także całe społeczeństwo. Zaznaczył, że temat miłosierdzia jest zagadnieniem centralnym dla teologii xxI wieku, gdyż stanowi ważną odpowiedź na współczesne znaki czasu. Miłosierdzie to Boży dar, a zarazem zadanie dla nas chrześcijan. Jest istotą przekazanego nam i przekazywanego przez nas innym przesłania Jezusa. Na koniec zachęcił uczestników do wnikliwego poznawania miłosierdzia Boga, kontemplowania go i przekazywania innym tej prawdy.

Sesji przewodniczył ks. dr hab. Michał Bednarz, wieloletni wykładowca Wydziału Teologicznego Sesja w Tarnowie. Jako pierwszy swój referat przedłożył ks. dr hab. Janusz Królikowski, dziekan Wydziału Teologicznego Sekcja w Tarnowie. Jego wystąpienie zatytułowane Miłosierdzie Boże między teologia i pobożnością. Wprowadzenie było - jak wskazuje tytuł - wprowadzeniem w tematykę. Wychodząc od łacińskiego tekstu psalmów „Universae viae Domini misericordia et veritas” (za Wulgatą, Ps 24, 10) oraz „Misericordia et veritas praecedent faciem tuam” (Ps 88, 15), zaznaczył, że miłosierdzie i prawda to dwa filary, na których opiera się z jednej strony Boże objawienie, a z drugiej teologia i pobożność. Podkreślił, że mówiąc o miłosierdziu Bożym, nie możemy ulegać fałszywej wizji, że mamy do czynienia z łatwą tajemnicą, gdyż jest ona trudna, zarówno na poziomie teologii, jak i pobożności. Ukazał to w oparciu o myśl św. Tomasza z Akwinu. Trudność w teologii można zawrzeć w dwóch pytaniach: gdzie jest miłosierdzie w męce Chrystusa? oraz dlaczego potrzebne było wcielenie? Odpowiadając na pierwsze, stwierdził, iż Chrystus jako człowiek mógł zadośćczynić za grzechy rodzaju ludzkiego, lecz aby podnieść całą naturę ludzką, potrzeba obniesienia do Miłosierdzia Bożego. Dlatego Chrystus jako prawdziwy Bóg mógł tego dokonać. Natomiast wcielenie było potrzebne, aby Bóg mógł dokonać tego, co zamierzał. Mógł to zrobić, co prawda, jednym aktem wszechmocy, lecz On nigdy nie czyni tylko tego, co konieczne, ale wybrał sposób lepszy i najbardziej odpowiedni - miłosierdzie. Bóg - okazując miłosierdzie - nie ogranicza się do minimum, ale czyni to ze wspaniałomyślnością (lub przeobfitością). Tutaj jest odniesienie do naszej pobożności - gdy czynimy miłosierdzie, nigdy nie możemy zadowalać się minimalizmem, lecz mamy dążyć do przekraczania siebie. Tutaj sytuuje się owa trudność na poziomie pobożności.

Drugi referat pt. „Kontekst biblijny tajemnicy Miłosierdzia Bożego. Miłosierdzie - sprawiedliwość” wygłosiła pani dr Joanna Jaromin z Wydziału 
Teologicznego Uniwersytetu Opolskiego. Na początku swego wystąpienia zauważyła, że często spotykamy się z twierdzeniem, że Bóg Starego Testamentu to Bóg srogi, karzący, sędzia, a w najlepszym wypadku Bóg sprawiedliwy, natomiast Bóg Nowego Testamentu to Bóg miłosierny, przebaczający Ojciec. Co zatem $z$ tym dysonansem zrobić? W odpowiedzi na to pytanie prelegentka zauważyła, że jest to wielkie uproszczenie, a nawet zniekształcenie obrazu Boga, wynikające z zawężenia pojęcia sprawiedliwości. Dalej stwierdziła, że miłosierdzie nie jest wykluczeniem sprawiedliwości, i odwrotnie. Bóg sprawiedliwy nigdy nie przestanie być miłosiernym, i odwrotnie (szczególnie widoczne w przypowieści o robotnikach w winnicy). Na kartach Starego Testamentu znajdujemy wychwalanie sprawiedliwości Bożej w dwóch aspektach: negatywnym - jako potępienie, ukaranie wrogów Izraela oraz pozytywnym - wyzwolenie i dobrodziejstwa udzielane narodowi wybranemu. Miłosierdzie nie jest - jak zauważyła prelegentka „wynalazkiem” Nowego Testamentu, gdyż objawia się już w Starym Testamencie. Na tle starotestamentowego pojęcia sprawiedliwości możemy popatrzeć na miłosierdzie. Ostatecznie to Jezus Chrystus jest obliczem Miłosierdzia Ojca. Miłosierdzie i sprawiedliwość to nie są dwie przeciwne rzeczywistości, ale dwa wymiary tej samej rzeczywistości. Bóg przekracza sprawiedliwość miłosierdziem i przebaczeniem.

Kolejnym prelegentem sesji był o. dr hab. Paweł Warchoł of Mconv, profesor Papieskiego Wydziału Teologicznego w Warszawie, który podjął temat: Jak dzisiaj głosić miłosierdzie Boże? W odpowiedzi na to pytanie stwierdził, że trzeba to czynić wszelkimi możliwymi sposobami. W pierwszym punkcie wystąpienia przedstawił istotę głoszonego miłosierdzia, w której zawiera się wizja Boga miłosiernego, bliskiego, czułego, solidarnego z człowiekiem, przebaczającego, ale jednocześnie sprawiedliwego. Głoszenie miłosierdzia jest wymogiem nawrócenia. W kolejnym wykładowca wskazał formy głoszenia: formy przepowiadania - homilie, kazania, rekolekcje; formy naukowe studia tekstów biblijnych, sympozja; przekaz środków masowego przekazu; wytwory szeroko rozumianej kultury - malarstwo, teatr, literatura, muzyka i inne zjawiska artystyczne; w końcu doświadczenie świętych Pańskich. Nową formą zauważoną przez prelegenta - na przykładzie archidiecezji łódzkiej - jest festyn o wymiarze społecznym. W ostatniej części podkreślił aspekt świadectwa, zaznaczając, że nie można głosić miłosierdzia, nie będąc świadkiem. Świat chętniej słucha świadków niż nauczycieli, a jeśli słucha nauczycieli, to dlatego, że są świadkami. Za św. Janem Pawłem II przypomniał, 
że tam gdzie świadectwo słowa jest trudne lub niemożliwe, potrzebna jest sama postawa uobecniająca postawę Chrystusa Sługi. Ewangelizując miłosierdziem, toruje się ludziom drogę do wspólnoty Kościoła.

Następnie głos zabrała Anna Czech, poseł na Sejm RP, dyrektor Wojewódzkiego Szpitala im. św. Łukasza w Tarnowie, nadto założyciel i prezes Fundacji Kromka Chleba. Jej wystąpienie pt. Po stronie miłosierdzia w Tarnowie było swoistym świadectwem tego, jak w rzeczywistości pomaga się potrzebującym w Tarnowie. Pani poseł omówiła bowiem działanie założonej przez siebie w 2003 roku fundacji. Wśród konkretnych dzieł miłosierdzia tej fundacji - dzięki ofiarności wielu firm i osób prywatnych - są: łazienka - miejsca, gdzie bezdomni mogą zadbać o swoją higienę, a także noclegownia; organizacja spotkań wigilijnych i wielkanocnych; informator dla osób samotnych, chorych „Tarnowska Opieka Domowa” o możliwościach korzystania z pomocy; Tarnowski Uniwersytet Trzeciego Wieku, przez który przeszło już ponad 1500 osób; objęcie patronatem wspólnoty Cenacolo polskiego domu w Porębie Radlnej; organizacja koncertów charytatywnych, spektakli; projekt mający propagować postawę św. Faustyny, aby zachęcić ludzi do dobroczynności. Najważniejszym, obecnie realizowanym dziełem jest budowa hospicjum Via Spei.

Piąty wykład wygłosił ks. dr Krzysztof Bułat, wikariusz biskupi ds. stałej formacji duchowieństwa diecezji tarnowskiej. W swoim referacie Kult Serca Jezusowego i kult Miłosierdzia Bożego: podobieństwa i różnice przedstawił kontekst historyczny ustanowienia święta Najświętszego Serca Pana Jezusa i jego rozwój oraz rolę kultu tej tajemnicy w życiu św. Faustyny, by następnie móc ukazać odrębność zrodzonego później kultu Miłosierdzia Bożego. Ową odmienność wykazał poprzez przedstawienie różnicy w istocie obydwu kultów, mianowicie innego przedmiotu, celu i form tych kultów. Szczególnie istotne jest ukazanie różnicy przedmiotu i celu. Przedmiotem materialnym (co czcimy) kultu Serca Pana Jezusa jest ludzkie serce Chrystusa, materialnym - właściwym Boska Osoba wcielonego Słowa Bożego, a formalnym (dlaczego czcimy) - miłość Zbawiciela ku rodzajowi ludzkiemu; natomiast w kulcie Miłosierdzia Bożego odpowiednio: obraz „Jezu, ufam Tobie”, boskie miłosierdzie w Trójcy świętej - miłosierdzie Ojca i Syna Bożego, miłosierdzie Trójcy. Cel kultu Najświętszego Serca Pana Jezusa to miłość człowieka do Boga jako odpowiedź na miłość Serca Bożego, szczególnie objawiająca się w wynagrodzeniu za grzechy i poświęceniu siebie, a w kulcie Miłosierdzia Bożego celem jest ufność do Boga i prośba o miłosierdzie względem bliźniego. 
Ostatnim prelegentem był ks. dr hab. Robert Kantor, wykładowca prawa na Wydziale Teologicznym Sekcja w Tarnowie. W wykładzie pt. Obowiązujace przepisy prawne dotyczace odpustów w Kościele katolickim przedstawił obowiązujące prawo Kościoła dotyczące odpustów. Na wstępie zaznaczył, że punktem wyjścia do rozumienia odpustów jest właśnie niezgłębione miłosierdzie Boże. Przypomniał kanoniczną definicję odpustu zawartą w kan. 992 KPK, gdzie czytamy: „Odpust jest to darowanie wobec Boga kary doczesnej za grzechy odpuszczone już co do winy”. Dalej wyróżnił rodzaje odpustów: zupełny i częściowy oraz warunki ich uzyskania: osoba ochrzczona i nieekskomunikowana, stan łaski uświęcającej, spowiedź sakramentalna, brak przywiązania do jakiegokolwiek grzechu, intencja zyskania odpustu, przyjęcie komunii, modlitwa $\mathrm{w}$ intencjach papieża oraz wykonanie czynności związanej z odpustem. Autor przypomniał zapis KPK, że tylko biskup Rzymu ma prawo przekazać władzę udzielania odpustów (kan. 995), oraz wyliczył odpusty zupełne zawarte w Enchiridion Indulgentiarum z 1999 roku. W związku z przeżywanym w Kościele Nadzwyczajnym Jubileuszem Miłosierdzia prelegent zaznaczył, że zgodnie z bullą papieża Franciszka Misericordiae vultus i jego listem do przewodniczącego Papieskiej Rady ds. Krzewienia Nowej Ewangelizacji z 1 września 2015 roku wierni uzyskali istnieje możliwość uzyskania odpustu zupełnego za odbycie pielgrzymki do wyznaczonych Drzwi Świętych połączone z sakramentem pojednania, uczestnictwem we mszy świętej oraz refleksją nad miłosierdziem; konieczne jest, by towarzyszyły tym celebracjom wyznanie wiary i modlitwa za ojca świętego i w jego intencjach. Wierni mogli też uzyskać odpust po spełnieniu warunków zwykłych i jednego uczynku miłosierdzia. Wskazał także możliwości zyskiwania odpustów przez fizycznie niezdolnych tego wykonać, chorych i więźniów. Na koniec podkreślił, że trzeba mieć świadomość, iż odpust nie może być traktowany jako swoisty bilet wstępu do nieba, ale jest doświadczeniem świętości Kościoła, który ma udział we wszystkich dobrodziejstwach płynących z odkupienia Chrystusa, aby przebaczenie rozszerzyło się aż po skrajności, do których posuwa się miłość Boga.

Sesję zakończył biskup tarnowski Andrzej Jeż, który podziękował prelegentom i uczestnikom i po wspólnej modlitwie udzielił - według przysługującego biskupowi prawa - błogosławieństwa papieskiego połączonego z odpustem zupełnym. 